\title{
Pb nanospheres in metamorphic zircon
}

\author{
MONIKA A. KUSIAK ${ }^{1}$, RICHARD WIRTH ${ }^{2}$, DANIEL J. \\ DUNKLEY ${ }^{3}$, LEONID SHUMLYANSKYY ${ }^{4}$, MARTIN J. \\ WHITEHOUSE ${ }^{5}$, SIMON A. WILDE ${ }^{4}$ \\ ${ }^{1}$ Institute of Geophysics, Polish Academy of Sciences, \\ Warsaw, Poland; monika.kusiak@igf.edu.pl \\ ${ }^{2}$ GeoForschungsZentrum, Section 3.6, Potsdam, Germany; \\ ${ }^{3}$ Faculty of Natural Sci., Univ. of Silesia, Sosnowiec, Poland; \\ ${ }^{4}$ School of Earth and Planetary Sci., Curtin Univ, Perth, WA \\ ${ }^{5}$ Swedish Museum of Natural History, Stockholm, Sweden;
}

Metallic $\mathrm{Pb}$ nanospheres, first discovered in zircon from granulite facies rocks of the Napier Complex, Antarctica [1], have also been documented elsewhere in ultra-high temperature (UHT) rocks (Kerala Khondalite Belt [2]) and in granulites from the Ivrea-Verbano Zone [3]. If the $\mathrm{Pb}$ nanospheres were formed during high- $\mathrm{T}$ metamorphism from radiogenic $\mathrm{Pb}$ that accumulated over time metamorphic rims should contain no nanospheres. Zircon cores and metamorphic rims in samples from two localities of $3.7 \mathrm{Ga}$ gneisses (Labrador [4] and Ukraine [5]) were examined. Tonalitic gneisses from Labrador were metamorphosed at $2.7 \mathrm{Ga}$ and $2.5 \mathrm{Ga}$, whereas enigmatic quartzose rocks from the Odesa quarry, Ukraine, were metamorphosed at $2.8 \mathrm{Ga}$ and $2.0 \mathrm{Ga}$. In both localities $\mathrm{Pb}$ nanospheres were found in metamorphic zircon of the earlier generation $(2.7 \mathrm{Ga}$ and $2.8 \mathrm{Ga}$, respectively). Hence, these were produced during later metamorphic events. The $\mathrm{Pb}$ nanospheres in the Ukrainian samples are extremely abundant and occur as both separate inclusions and in aggregates. The reason for these variations will be evaluated.

This research was performed within a Humboldt Fellowship to MAK and NCN POLONEZ UMO-2016/23/P/ST10/01214 funded through the EU H2020 research and innovation programme under MSCA grant agreement 665778 to DJD.

[1] Kusiak et al., 2015 PNAS 112, 4958-4963. [2] Whitehouse et al., 2017, Miner Petrol 111,467-474. [3] Kusiak et al., 2019, GCA 292, 20-30. [4] Kusiak et al., 2018. Chem Geol 484, 210223 [5] Claesson et al. 2016. Prec Res 272, 1-11. 